\title{
Poverty In The Developing Countries: A Multifold Curse
}

\author{
Zaeema Asrar Mohiuddin \\ Assistant Professor, Department of Commerce \\ University of Karachi \\ Hasan Raza \\ Assistant Professor, Department of Commerce \\ University of Karachi \\ Muhammad Farrukh Aslam \\ Lecturer, Department of Commerce \\ University of Karachi
}

\begin{abstract}
As poverty is a systematic curse that affects many macro factors of economy, policies \& planning not only in developing countries but throughout the world therefore it becomes a socioeconomic issue on national \& international level and requires an effective framework. The purpose of the study is to identify the reasons of poverty \& implications of allocated assistance by IMF \& WB in the developing countries and exploring the responsiveness of international efforts to minimize the level of poverty. World Bank (WB) in the collaboration of IMF (International Monetary Fund) works for the international goal to reduce poverty through its planning \& projects, provides aids to those countries that are economically weak or they are stabilizing their performances to improve their economy and controls it by SAP (Structural Adjustments Program).However, these aids $\&$ assistance are affected by political powers, corruption and mismanagement in developing countries and mostly it could not reach to allocated area that helps poverty to sustain. The study focuses on theoretical mechanics of poverty in the light of structural adjustments program and emphasizes on the need of effective governance and state citizen relationship. The result of descriptive analysis explained that aids \& assistance do not reach to the deserving one because of political vested interests and corruption or spur inequality. These aids reach optimal levels only if there will no preferred creditor notions, state will be committed $\&$ responsible and good governance will also be required to reduce poverty with the help of unanimous efforts.
\end{abstract}

Keywords: Poverty, Political Economy, Socioeconomic, Recession.

\section{INTRODUCTION}

Easterly (1999) described "Eradication of Poverty" is the proclaimed millennium goal of the World Bank. To stress and emphasize their commitment, the World Bank even has this goal engraved in its main office. In fact, perhaps all the activities of the World Bank [WB] are directional towards achieving this goal. The WB in function provides guidance and council to those nations that are suffering from economic hardships. It works in close affiliation with the International Monetary Fund [IMF], the latter being an international financial institution. The IMF like the WB functions to assist crumbling economies, yet their mode of assistance being financial and technical makes them more influential, and their dictum more binding on their clients.

It is worth re-establishing here that the formation of the WB and the IMF were based on an international agreement after the economic backlash of the WWII. The IMF was born as the result of the famous meeting between leading nations of the world, the "Bretton Woods 
Agreement". The consensus reaching the need of an international financing institution was fueled by the contingency-based provision of assistance to any country that found itself trapped in a deficit or liquidity trap. The IMF collected funds from its members, who enjoyed voting powers based on the extent of their contribution. The purpose of its existence was assistance and guidance for an economically struggling country to recover from the shock. Hence focus elements of the IMF have always been the economic performances and growth avenues; explained by Obstfeld and Krugman (2000).

Philip (2004) elaborated that the WB focuses on the complete political economy of the Country. The WB recognizes socioeconomic elements like inequality and poverty with respect to the role that they play in determining the long-term growth of the economy. Efforts of the WB have been to support countries in overcoming these barriers to success. In effect, the WB and the IMF should then be complementary organizations without any contradiction of organizational goals.

Poverty is one such element that is not only a characteristic of developing countries that the WB aims to reduce, but also a result of its policies and operations. Despite the existence of the WB and the IMF, poverty has perpetually increased in the world.

In fact, poverty is the major developmental problem of this century with more than half of the world living below the Two Dollar-a-Day benchmark; Annan (2000). To overcome this characteristic of the developing world, economic growth was stipulated as a necessary and sufficient condition. By the time mass poverty was "discovered" and acknowledged as a major developmental issue, the world was experiencing the era of growth through industrialization and poverty reduction because of the trickle down of this growth; Explained by Escobar (2001). Growth theories put forward by Harrod-Domar and Arthur Lewis dominated the economics of the developing world. The WB and other influential schools of economics picked up these theories and suggested their implementation as the path to success, based on the experience of the developed nations.

IMF initiated new programs to facilitate the indebted states in returning the outstanding loans. These included certain structural change programs, adjustment lending on prior loans, more financial assistance etc. The effect of these is widely researched and disseminated as being ambiguous in determining whether these efforts enhanced growth and alleviated the poverty levels, these two being the main goals.

It is within this framework that this paper will reassess poverty, explore its responsiveness to international efforts, its relation to economic growth and most importantly, changes in the level and extent of poverty considering the pro-poor plans and aid that is exclusively directed towards poverty reduction. In conclusion, the paper seeks to undermine the mechanics between growth, aid and poverty. Also, the highly relevant issue of the role of good governance will be included in the query. Moreover, analysis will be offered regarding the relationship between the state and the citizens, to examine the socioeconomic context of poverty.

\section{POVERTY}

Poverty can foster a lot of definitions. What economists usually limit to a certain income level is perhaps the most tangible of definitions for poverty. Escobar (2001) further explained in their discussion about poverty that the development discourse refers to a certain "problemization" of poverty, which at best is a socioeconomic construct and has established certain values and politics to the frame. It promotes that poverty has been overly objectified by the financial institutions and that it is more diverse and subjective than the WB defines it to be. 
The reality and face of poverty is all but too real, and too stark for debate's sake. The appalling standard of life, the malnourishment, the almost negligible state health and education, the helplessness of those without any assets, are all too transparent. The problem of defining becomes important as it instructs us in finding who the poor are and what can be done for them effectively.

Esteva (1992) described poverty for all its variant aspects can be associated to underdevelopment. If development can be defined by Sen's freedom approach, then underdevelopment and poverty are states of being depraved of essential freedoms. These freedoms are related to the right to economic and social opportunities. Freedom has also been discussed as having access to the basic entitlements, and as having the right and opportunity to exercise your capabilities. And in a virtuous circularity, the entitlements we have increase our capabilities, which in turn increase our basic entitlements. Not being free would pertain to being deprived of one's rightful entitlements. Of being isolated from opportunities of improvement; as mentioned by Sen (1999).

For the sake of measurement and econometric study, this paper will establish poverty as living below a certain income level. In a subsequent section, which deals with the state-citizen relationship in the context of aid allocation and poverty, the paper will revert to dealing with poverty as a complex and non-monolithic concept. With the advent of time, poverty statistics have shot up. With 410 million people predicted to be living below the absolute poverty line by 2015; Annan (2000), absolute poverty has been said to decline but the number of people living in absolute poverty has increased. According to Annan there are at present 110 million children in the developing countries that don't attend primary school. Financial crises have also taken their toll on the poverty levels, with poverty increasing in Brazil, Argentina and East Asian countries after their economic fiascoes; Annan (2000). It is argued that poverty has increased because of the IMF's involvement in the economic affairs of a country. "When the IMF and the WB arrive in southern countries, corporate profits go up, but so poverty and suffering. Decades of promises that a little more short-run pain will bring long term gain have exposed the IMF and WB as false prophets whose mission is to protect those who already have too much power and wealth" MacEwan (2002).

\section{THE GOOD, THE BAD AND THE UGLY}

The IMF has been explained as an institution that functions to rid economic recessions. Despite emphatic reference to poverty as one of the main aims of its packages, the IMF is seriously challenged in evidence of its past involvement in countries. The reasons for this criticism are its structural adjustment programs and the general allocation of assistance, which has directly hurt the poor. In this way, the IMF and Aid are said to be the apparent good, which creates the ugly SAP's while poverty being the bad is perpetually burgeoning. In similar vein, the allocation of aid has great impact on poverty reduction, since the main aim of aid through international agencies and bilateral grants, has been reduction of poverty; Easterly (2001).In the aftermath of the Debt Crisis of the eighties and the subsequent dismal growth, the IMF featured as a major player in the economies of the indebted countries. Today, the IMF faces populous disrepute after the crashing of several economies that at one point exemplified the success of its structural adjustment programs. The main causes of this disrepute as mentioned are the Structural Adjustment Programs [SAP] and different adjustment loans that it mandates to indebted or repressed economies, as a precondition for financial assistance; Easterly (2001). The SAP's mainly constitute of policy reforms that compel openness in trade \& the deregulation of protected sectors. Feldstein (2002) elaborated that it requires devaluation of 
the currency and a tight fiscal policy; shrinking out outlays like pensions, welfare spending, social safety nets, subsidies etc. Chenery \& Strout (1966) explained The SAP's follow a certain economic logic, namely the Neo Liberal understanding of growth. The policy references of the SAP's garner their theoretical underpinnings from this school, which declares that for economic growth the state should be rolled back, trade should be open and interventions are minimal, protection should be removed and that market forces be deterministic rather than state decisions.

Aid granted to countries follows many reasons and benefits. While many part with it for reasons other than poverty reduction; Alesina \& Dollar (1998), aid that is generated for the poor is often conditioned to similar prerequisite adjustments to enhance the effectiveness of the aid. These adjustments are similar in nature and impact as the SAP's. Collier \& Dollar (2001) described furthermore that like the SAP's, aid has often been found to increase inequality and have little impact on poverty alleviation.

\section{THE POVERTY MECAHNICS OF THE SAP}

Now poverty is an essential outcome of the SAP's because the SAP's propagate policies that adversely affect the poor or the low-income households.

The SAP's are more of a precondition to further financial assistance. A country agrees to its conditions because it fails to pay back IMF's loans. The SAP's call for drastic change in the structure of the economy and more importantly in the resource allocation. The IMF assumes that the indebted country is engaged in populous spending, which caused its current deficits. Hence the first change is the cut back of fiscal expenses. These expenses involve public wages, subsidies, public investments etc. their basic affect is the loss of income and entitlements for the poorest and hence demand is thinned out as explained by Fronti, Miller \& Zhang (2005). Furthermore, withdrawal of the state from enterprises introduces private ownerships that are rational agents and whose interest is profit making, not state welfare. Possible outcomes of privatization are higher prices and unemployment.

MacEwan (2002) explained that the second change involves opening the borders for trade and financial assets. This move is advocated based on the experiences of the East Asian countries, yet these very countries have had reported poverty increases after their crashes. Fronti, Miller, and Zhang (2005) described that opening of trade wipes out infant industries and often parts of the informal economy, which provides sustenance to most the people in the developing countries. Moreover, opening of financial markets opens doors to speculative attacks, and efforts to defend the currency require the increase in money supply and hence inflation is a definite outcome. The reduction in purchase power removes major nutrition and schooling from the lives of the citizens, driving them to a lower standard of life.

Now, for lowered wages in the SAP's the onset of inflation is treacherous. Many violent public riots have broken out in developing countries following inflationary pressures and falling wages. What many call the "whirlpool towards economic recession and a major collapse"; Fronti, Miller \& Zhang (2005). looms as a larger reality under the SAP's. The case of Argentina is classic representation of how the IMF can ruin an otherwise healthy middle income economy.

Baker and Weisbrot (2002) described that there are yet more channels through which these SAP's affect the poor. Examples of the Peso Crash in 1997, the Mexican Crash in 1999, the Argentine Collapse in 2001 and then Euro Crises in 2012 (due to which Greece, Portugal, Ireland, Cyprus, Spain and Italy were bailed out by IMF) are some of the instances that warn 
against the evils of the IMF. In all the cases, one clearly observes the IMF back out as an economy shows signs of collapse after implementing the SAP. In fact, according to Thomas (2005), the IMF has been criticized for shrugging off any responsibility of the economic collapse. An economic collapse is perhaps of historic importance for the people of that country. Easterly (2001) explained that for the IMF, it is a mere instance of a country that failed to implement the SAP's appropriately.

Burnside and Dollar (1997) elaborated that naturally, the public of the SAP accepting nations must suffer intense hardships. It is worth mentioning here that growth is found not to be significantly attributed to financial assistance or aid independently. Now, growth has been witnessed in countries under the SAP's. This growth, while it was there, had no effect on the poverty levels. Ironically the responsiveness of poverty to growth has been found to be negative, which means that poverty increases as growth is experienced. Moreover, Easterly (2001) found that during recessions, the poor are not that drastically affected by the state of the economy.

\section{GOVERNANCE AND SELECTVITY PRINCIPLE}

The IMF has declared that it is lack of good governance that creates policy failure. In fact, in the debate regarding the allocation of funds and assistance to the developing countries, literature now reveals that often the failure rests on part of the recipient's commitment and transparency. Furthermore, as Burnside and Dollar (1997), it is found that growth is only positively related to foreign assistance depending on nature of the recipient country's regime.

Indeed, it has been asserted by laymen and researchers alike Boone (1994) that the SAP's do not warrant either growth characterized by inflation, speculation, unemployment and privatization of inefficient state enterprises. Whether the IMF's policy package delivers the growth it promised rests on factors that are exogenous to the entire debate. These include softer and intangible issues like governance, nature of the ruling regime, the state of macroeconomy, the political condition etc. Much research has been done on the effectiveness of aid and foreign assistance from which Dollar and Pritchett (1998) elaborated that the significance of these factors on growth is much more than the postulated policy reforms and adjustment.

To maximize the effectiveness of aid, Collier \& Dollar (2001) found that aid is better given to countries based on policy performance rather than mere need. This is often called the selectivity criterion. What it proposes is maximization of poverty alleviation through more efficient allocation of aid.

Rational as it sounds, this principle has been criticized for its defeating the original purpose, that being the eradication of extreme poverty. There is no doubt that the effectiveness of aid is greater for better governed countries, yet these better governed countries are less needy than the poorest ones. By giving aid to the not so poor will inevitably increase inequality and create a greater poor population. It is not fair, because having lack of institutional guarantees should not affect the aid per capita that an individual receives. Moreover, Cogneau (2005) explained that measuring good governance can be difficult and its indices are varied and often produce variant resultsxxiii.

Another interesting aspect of delving into aid allocation would be the fact that often, aid is given on political and national reasons, regardless of poverty levels. Moreover, aid has been given to regimes other than democratic solely because the country was a former colony. The 
fact that this kind of aid flow is present and is part of a much greater political reality, takes away from aid its chances of absolutely reducing poverty, achieving the millennium goal; as described by Alesina and Dollar (1998).

One more rather interesting aspect of the governance debate is despite the claim by the donors that they prefer transparent and committed recipients, Alesina and Weder (1999) found out through various corruption indices that being corrupt doesn't affect the aid allocated your way, in fact, empirically aid has gone more to the corrupt governments. This empirical result has more than one implication. First, it affirms after Alesina's 1998 paper that allocation of aid follows patterns other than targeting the poorest. Secondly it might also suggest that aid allocation increases corruption and aid.

The second suggestion might be more meaningful because allocation of aid not to the poorest will obviously cause corruption because that aid will be more fungible and without accountability. Considering that colonies and political allies are preferred recipients. In fact, aid if measured as a fraction of fiscal budgets, is huge for colonies and allies. Freeing so much fiscal outlays, the remaining aid is spent on wasteful consumption.

Fact that has been tested empirically by Boone (1996), now, one of the causes of bad governance is unearned state revenue as according to Moore (2001). This means income sources that are not generated from the economy. Whether it is natural resources or foreign assistance, unearned revenue has been found to cause bad governance, because the state is not accountable for service provision or the fact that there are no pressure groups. Whatever the case be, excess aid allocation to certain countries creates bad governance in the form of corruption and global inequality. So, relevance of the selectivity principle is redundant if there's the political flow of aid, because this mars poverty alleviation in several ways.

\section{STATE-CITIZEN RELATIONSHIP AND POVERTY}

Discussing the relationship between state and citizens provides meaningful indicators as well as assessing poverty more realistically.

The state citizen relationship is perhaps the most reflective index of corruption and transparency. If the state is accountable to its citizens, then there is automatic negation of any corruption or governance. If the state citizen relationship is weak, then one might anticipate that the government need not be accountable and hence chances of fraud and corruption are lower. For clarification, a strong state-citizen relationship is believed to be in Venezuela where there's a full welfare system, many demonstrations every day that demand better rights for labor and workers which are mostly granted etc. A weak state citizen relationship example can be any military regime where the state is not answerable to its people.

Moreover, poverty transcends beyond an economic reality. It is as social a reality as it is economic. Poverty isn't restricted to incomes; it is a complex measure that accounts for the individual's assets and opportunities to cash in on those assets.

The world over, one hears of the landless movements, the Zapatista movement in Mexico, the landless farmer's movement in Bangladesh, the Kachi Abadi movements in Pakistan etc. are all images and manifestations of the same problem: poverty.

For developing nations around the world, this relationship is withering away because global political economy is moving in a direction where policies like the SAP's must be implemented even though these are generic and regardless of ground realities of each country. Privatizations 
are a common practice. Opening of trade and lifting of barriers is being witnessed all over the world.

While there's no determined relationship between growth and openness, or financial development and growth, and economists have proved that the general macroeconomic factors play a far more important role in the development of an economy, countries are still attracted to aid packages and financial assistance, in hope of economic prosperity. At the same time, they are willing to reduce fiscal expansion to whatever amount needed, in hope that the short-term pain will result in some long run gain. However, the promised growth has not been witnessed yet.

The world GDP is said to increase by $200 \%$ because of trade liberalization, yet liberalization has not transcended into poverty alleviation for the poorest, reason being inequality and unjust distribution of resources. To a large extent, the prevalent poverty is because of a weak citizen relationship with the state, as well as economic realities that make it even more difficult to establish this relationship.

\section{CONCLUSION}

This paper examined poverty as a socioeconomic issue that is most definitely an international developmental goal. Efforts to alleviate it like IMF funding and Aid by the developed world are incomplete and insufficient in reaching the millennium goal of eradicating poverty. Reasons for this outright claim are the vested political interests on an international as well as national level that hinder aid from reaching the most deserving candidate. In effect, aid and assistance should be viewed with caution, because based on the situations on ground for the recipient country; the allocated aid might just cause corruption or spur inequality, both of which are intermediary elements towards poverty.

Aid or any kind of assistance will only reach the optimal effect, if there are no structural prerequisites or preferred creditor notions, which draws out precious resources from the already poor states. This of course, is only a necessary condition. The sufficient conditions would involve checks on governance, responsible and committed behavior by the state and allocation to the most deserving.

\section{References}

Alesina, A., \& Dollar, D.,(1998). Who Gives Foreign Aid and Why? National Bureau of Economic Research,Working Paper, 6612.

Alesina, A.,\& Weder, B.,(1999). Do Corrupt Governments receive less Foreign Aid? National Bureau of Economic Research,Working Paper, 7108.

Annan, K., (2000, Oct 17). The UN International Day for Poverty Eradication.

Baker, D., and Weisbrot, M.,(2002). What Happened to Argentina? Centre for Policy and Economic Research.

Boone, P.,(1996). Politics and the Effectiveness of Foreign Aid. European Economic Review, 40, pp 289-329.

Burnside, P.,\& Dollar, D.,(1997). Aid, Policies and Growth. World Bank Policy, Research Paper, 1777.

Boone, P.,(1994). The Impact of Foreign Aid on Savings and Growth. The London School of Economics,MIMEO.

Chenery, H. B.,and Strout, A.,(1966). Foreign Assistance and Economic Development. American Economic Review,56(4), part 1, pp 679-733.

Collier, P., \& Dollar, D.,(2002). Aid Allocation and Poverty Reduction. European Economic Review, 46. 
Collier, P., \& Dollar, D.,(2001). Can the World cut Poverty in Half? How Policy Reform and Effective Aid Allocation can help meet the International Developmental Goals? World Development, 29.

Cogneau, D.,(2005). A Critique of the "Selectivity Principle" in aid allocation. AFD Research Department.

Dollar, D., Pritchett, L.,(1998). Assessing Aid: What works, what doesn't and why? World Bank policy research report, Washington, D.C., 18295.

Easterly, W., (1999).Our Dream is a World Free of Poverty. The Effect of International Monetary Fund and World Bank Programs on Poverty.

Easterly, W.,(2001). IMF and World Bank Structural Adjustment Programs and Poverty. World Bank Publications, IMF Research Conference.

Escobar, A.,(2001). Encountering Development: The Making and Unmaking of the Third World. New Jersey, Princeton Press, pp 21-54.

Esteva, C.,(1992). Development in the Development Dictionary. Princeton University Press.

Feldstein, M.,(2002). Milton Friedman and Public Economics. National Bureau of Economic Research. http://www.nber.org/feldstein/MiltonFriedmanPublicSector Economic

Fronti, J., Miller, M., and Zhang, L.,(2005). Credit Crunch and Keynesian Contraction: Argentina in Crisis. Centre for Economic Policy Research, CEPR, Discussion Paper, 4889. http://www.cepr.org/pubs/dps/DP4889.asp

MacEwan, A., (2002). Economic Debacle in Argentina: The IMF Strikes Again. Third World Traveler.

Moore, M.,(2001). Political Underdevelopment: What Causes 'Bad Governance. The Institute of Development Studies, pp 23-33.

Obstfeld, M., and Krugman, P. R. (2000). International Economics: Theory \& Policy. Addison Wesley, 5.

Philip, K., (2004). What does political economy tell us about economic development and vice versa? Development Research Group, The World Bank 1818 H St. NW Washington, DC 20433.

Sen, A., (1999). Development as Freedom. New York: Oxford University Press.

Thomas C. D., (2001, Dec. 20).International Monetary Fund, Press briefing. http://www.imf.org/external/np/tr/2001/tr011220.htm

Yilmaz, M. H., Ali, F., Mubeen, M., \& Waqas, M. Income Inequality and Its Measures: Evidence from OECD and European Countries.

Zubair, Muhammad and Burney, Anwar Irshad and Sarwat, Syed Salman and Mubin, Muhammad, Macroeconomics Relations between Exchange Rate Instability, Exchange Rate Volatility, Trade and Economic Growth Variables: The Case of Pakistan. Journal of Economics and Sustainable Development, Vol.5, No.13, 2014. Available at http://dx.doi.org/10.2139/ssrn.2534839 